\title{
Management of the Implementation of Innovative Methods in the Analysis of the Activities in Life Insurance Companies at the Independent Region
}

\author{
Yuliia Melnychuk $^{1^{*}}$ and Liudmyla Chvertko ${ }^{2}$ \\ ${ }^{1 * 2}$ Pavlo Tychyna Uman State Pedagogical University, Sadova str, 2, Uman, Ukraine \\ ${ }^{1 *}$ melnichyk_yuliya@ukr.net
}

\begin{abstract}
This article aims at solving the problem of improving financial analysis in the field of insurance business. The purpose of this work is to identify the impact of the application of methods of assessing of activity the life insurance company for future periods. The necessity of developing the life insurance market has been proved, as the insurance sector is an integral part of the financial market of the country and the world as a whole. The article reveals the modern theoretical and conceptual principles of life insurance: adds reliability to the development of business and the economy as a whole; helps to improve resource structures and intensify through investments in the most efficient areas of management funds aimed at organizing economic security; ensures the rational formation of the use of funds intended for the implementation of state social programs (health care, pensions, financial education); creates reserves of funds that are a real source of growth and coverage in the event of major natural disasters and accidents; organize jobs, form the infrastructure of the financial market. The life insurance market in Ukraine is analyzed. The newest elements of the analysis of life insurance companies' activity are offered: forecasting and planning of increase of the sizes of the authorized capital, reserve capital, own capital and the registered capital of insurance companies. The advantage of an in-depth financial analysis of the state of the insurer, which assists in making important management decisions, is proved. Based on the research, conclusions are drawn about the positive effects of using new areas of analysis of the financial state and the management of the company.
\end{abstract}

Keywords: Management, Financial independence, Region, World trade organization, Share capital, Equity

\section{Introduction}

The life insurance market in every country is an indicator of the economy and sustainable development of entrepreneurship. When stability and welfare of the country reaches a certain level, both workers and employers begin to think about their future, to ensure their old age, to finance the risks that exist in every person's life. The rapid aging of the population of all countries exhausts the financial capacity of citizens, which leads to a low level of health care and pensions. Life insurance enables you to ensure daily protection of a person - both today and in the future. This leads to the emergence of two effects - the state has additional long-term funds that provide financing for investment projects, which contributes to the further

Article history:

Received (May 15, 2021), Review Result (July 1, 2021), Accepted (August 15, 2021) 
development of the country's economy; citizens receive insurance protection, accumulation for future periods, and hence - protection of human interests.

Insurance in modern conditions is one of the fastest growing sectors of the economy. The insurance market itself is a guarantee of financial and social protection of the population. One of the most important factors in improving the investment potential of the market is the growth of the share of life insurance, which provides the possibility of long-term investments.

There is a need to strengthen insurers' financial security and ensure the stability of their functioning. Due to the complexity and diversity of external and internal financial relations, there is a need for highly effective management of the finances of insurance companies, which is a prerequisite for the formation of their financial security. First of all, this management is ensured by analyzing the indicators of financial stability of the insurer as an element of the financial safety of the insurance company. Financial stability is one of the most important characteristics of financial security of insurers from a long-term perspective.

In order for an insurance company to survive in conditions of fierce competition and be profitable and profitable, management must have a method of financial analysis, have a certain information base for its implementation and appropriate qualified staff to implement this method in practice.

Financial analysis is one of the most important management functions. It makes it possible to determine the competitiveness of the business entity in a market economy. That is why the introduction of innovative methods of analysis in the activities of life insurance companies is an urgent issue of modern business.

It is evident that the question of the application of new methods of analysis of the activities of the life insurance companies in the independent region is relevant and requires further research.

\section{Analysis of recent research and publications on the problem}

A considerable scientific contribution to the study of problems of the analysis of the activities and functioning of insurers was made by domestic and foreign scientists who studied the life insurance problems: A. Alexandrova, V. Bazylevych, V. Baranova, N. Vnukova, K. Voblia, I. Gabidulin, O. Gamankova, V. Hetman, Yu. Melnychuk, O. Zaletov, O. Zaruba, M. Klapkov, A. Knessler, D. Martsenishin, S. Osadets, A. Tarkutsiak, I. Tkachuk, T. Fedorova, J. Shumelda, V. Furman, T. Nazloyan, M. Pickard, M. Popov and many others. However, it is worth taking into account the current needs of life insurance and continue research on this issue.

The life insurance market in every country is an indicator of the economy and sustainable development of entrepreneurship. When stability and welfare of the country reach a certain level, both workers and employers begin to think about their future, provide their old age, finance the risks that exist in all people. The rapid aging of the population of all countries exhausts the financial capacity of citizens, which leads to a low level of health care and pensions. Life insurance enables you to ensure the daily protection of a person - both today and in the future [1].

Creating a stable national insurance system will help create an effective mechanism for preventing dangers and life threats. To achieve this, the following tasks are needed: strengthening the stability and reliability of insurers; state regulation and supervision of the tariff policy of insurers; improvement of the legal basis for the activities of the insurance market participants; formation of directions and approaches to the implementation of voluntary and obligatory types of insurance taking into account regional needs; creation of a favorable tax regime in order to stimulate the development of the insurance industry [2]. 
According to Cumminsa [3], the goals and tasks of the current stage of development of the insurance market of Ukraine require the improvement of the directions and methods of economic activity (the most important element of which is financial activity), methodologies for assessing the results of the economic activity of insurance companies, among which the most important place is financial sustainability.

It is to be agreed that improving the methodology for conducting financial analysis will lead to positive changes in the making of managerial decisions.

It is worth agreeing with Veiga [4] that an important component of the financial safety of an insurance company is solvency, which means the ability of the insurer to fulfill in all circumstance's monetary obligations in accordance with the law and concluded insurance contracts. The conducted studies allow determining the financial security of an insurance company - this is the ability of the insurer to perform assumed insurance and other obligations, provided that the level of financial stability of insurance operations is maintained. Further research deserves the question of selecting indicators for assessing insurance activity and insurance process, assessing the value of insurance business as part of the financial safety of the insurance company.

A modern strategy for the formation of a competitive model of the Ukrainian economy should be oriented towards a powerful overall economic and innovation breakthrough. At the same time, speaking of innovations, we understand them not only in the scientific and technological context, but also in economic reform. We do not consider economic reforms as innovative, and this is not a coincidence, but it is worth changing that opinion [5]. Research should also be aimed at improving the financial analysis and evaluation of enterprises, which will be an element of innovation as well.

A special place in this matter is the financial analysis of the company's activities, since the regular analysis that makes it possible to achieve the economic efficiency of the operation of the insurer. Given this, there is a need for a more detailed theoretical and methodological study of the analysis and assessment of the financial and economic efficiency of the insurance company. The consequence of a positive financial state is the increase of corporate partners in investing funds [6].

\section{Methodology and data}

In a scientific study used a set of general and specific methods which are interrelated and applied research in a logical and consistent communications: methods of structural and logical and conceptual analysis ascent from the abstract to the concrete, synthesis studies on the conceptual apparatus life insurance study of the integrity, unity and interconnection of its subjects; historical method - to consider the evolution of scientific views on the role of life insurance in society and in the economy; methods of information-logical analysis - for characterization and assessment of the insurance company; table-graphic method - for the visual display of the dynamics of absolute and relative indicators; trend analysis and factor analysis - in determining opportunities to improve the financial condition of the insurer; techniques of abstract logical method - for theoretical generalizations and draw inferences.

Based on the analysis of the legal framework, we apply a number of transformations and ratios to increase the capital of the insurance company. Since the company was established in 2000 , it is allowed not to increase the amount of authorized capital, but thus the company loses its leading position among other life insurers. We believe that TAS Life Insurance Company should start gradually increasing the size of the registered fund now, as such an increase should have taken place 5 years ago. 
We will calculate the gradual increase based on the fact that the company currently has 1.5 million euros of registered capital, its increase should reach 10 million euros in 5 years.

We propose to make such an increase according to the formulas:

$$
\begin{gathered}
S F 1=S F b p+X \\
S F 2=S F 1+X \\
S F 3=S F 2+X \\
S F 4=S F 3+X \\
S F 5=S F 4+X \\
X=(S F e p-S F b p) / 5 \text { years }
\end{gathered}
$$

Where,

SFbp - statutory fund at the beginning of the period;

SF1...5 - statutory fund each subsequent year;

SFep - statutory fund at the end of the period;

$\mathrm{X}$ - the amount of the authorized capital increase for the year.

The information base of the study is the main provisions of the relevant legislative and normative acts of Ukraine; statistics and analysis of the Ministry of Finance of Ukraine, the insurance company, rates insurance rating "Insurance Top"; scientific works of domestic and foreign scientists.

\section{Research results}

In today's economic conditions, taking into account transformation processes, there is a rethinking of the system of protection of legal entities and individuals from material costs, which can lead to unpredictable insurance cases (natural disasters, accidents, financial risks in obtaining loans, etc.). Thus, through the insurance system, the state provides protection of the population as a result of the occurrence of insured events, and also provides effective protection of business activity. Insurance and the insurance market are fundamentally important for socioeconomic and investment development both in the national market and internationally [7].

The Law of Ukraine "On Insurance" of March 7, 1996 defines the concept of "insurance" as a form of civil-law relations for the protection of property interests of citizens and legal entities in case of occurrence of certain events (insurance cases) specified by the insurance contract or current legislation, at the expense of money funds, which are formed by payment by citizens and legal entities of insurance payout (insurance payments, insurance premiums) [8].

An interpretive dictionary of an economist interprets the definition of insurance as a system of economic relations, which includes the formation of funds from the society, association, enterprise and population of a special fund and its use for the reimbursement of property losses from natural disasters and other adverse phenomena, as well as for providing citizens (or their families) assistance in the event of various events in their lives (reaching a certain age, disability, death). Insurance is property or personal. It can be voluntary and mandatory. In Ukraine, along with a public insurance organization, there are many alternative insurance companies. 
In addition, the insurance:

(a) adds reliability in the development of business and the economy as a whole;

(b) helps in improved resource structures and intensify through investments in the most effective spheres of management funds aimed at the organization of economic security;

(c) provides rational formation of the use of funds intended for the implementation of state social programs (health care, pensions, financial education);

(d) creates reserves of funds, which is a real source of growth and coverage of losses in the event of major natural disasters and accidents;

(e) organize workplaces, form the infrastructure of the financial market.

The process of becoming a modern insurance market in Ukraine began with deep socioeconomic reforms.

The main purpose of the development of the insurance market is to increase the level of insurance protection of property interests of individuals and legal entities, reduce the state's expenditures on preventing and eliminating the consequences of natural disasters, catastrophes, technological accidents, and the formation of effective market mechanisms for attracting investment resources into the national economy through the effective functioning of the insurance market services taking into account international experience, application of modern market infrastructure and financial instruments [9].

If you explore the region, then the insurance in the independent region gives the possibility of solving complex financial and social development issues that fall within the competence of the appropriate level of territorial administration on a legal basis, using financial, economic, and logistical resources of the region, while independently managing the results achieved, meeting the needs of the region, taking into account the national interests.

The total number of insurance companies in the insurance market as of 31.03.2019 was 292, including SK "life" - 32 companies, non-life insurance company - 260 companies, respectively, as of 31.03.2018, the number of insurance companies was equal to 307, including SK "life" 39 companies, non-life insurance company - 268 companies) [10]. In the first quarter of 2019, compared to the first quarter of 2018, the amount of gross insurance premiums grew by UAH 722.6 million (6.6\%), and net insurance premiums grew by UAH 1712.1 million (26.7\%). The increase in gross insurance premiums occurred almost in all types of insurance. The share of net insurance premiums in gross insurance premiums for the first quarter of 2019 amounted to $69.9 \%$, which is $11.1 \%$ more than in the same period in 2017.

During the analyzed period, the number of concluded insurance contracts increased (by 19531,9 thousand transactions or by $70,1 \%$ ), while on 491,2 thousand (or 3,1\%) contracts, the number of voluntary insurances increased [10].

According to the results of last year, collected 1.4 billion UAH insurance premiums. The total volume of insurance reserves for 2018 decreased by $31.1 \%$ compared to the same period in 2016 and amounted to UAH 2.6 billion. The size of the insurance payments amounted to 217.2 million USD. At the same time, the assets of these companies as a result of 2018 amounted to 3.2 billion UAH, and the total authorized capital of participants - 190.8 million $\mathrm{UAH}$.

According to insurance contracts for reaching insured retirement age, there was a decrease in the number of bonuses by $68.4 \%$, (UAH 3 million), under other contracts of accumulation insurance - an increase of $0.12 \%$ (UAH 875.7 million). According to life insurance contracts, only in case of death of insurance premiums increased by 3.3\% (84.5 million UAH) compared 
to last year. According to other life insurance contracts, insurance premiums increased by 2018 compared to 2017 by $7.1 \%$ (UAH 413.4 million).

It should be recalled that the project League of insurance organizations of Ukraine "Open Insurance" in the context of life insurance companies is divided into two categories: internal data (used for analysis directly by the companies participating in the project) and external indicators that are posted on the LIOU website. Data for 2018 were provided on a voluntary basis to life companies of PJSC TAS Life, KD Life, MetLife, ASKA-Life, and PZU Ukraine Life Insurance [10].

According to the rating "Insurance Top" according to the results of the companies in 2018 [11], the main players in the life insurance market were PJSC "TAS Life", PJSC "MetLife", Insurance Company "Unika Life", Insurance Company PZU "Ukraine Insurance Life", "Grave Ukraine" and others.

PJSC "Insurance group TAS" works in the insurance market of Ukraine since 1998, is an integral part of the TAS Financial Group, which also includes: TAS-Kommerzbank, PJSC "TAS-Investbank", PJSC Insurance Company "TAS", PJSC "Insurance company TASCapital", subsidiary company "RoTAS" (Russia) and other financial institutions and industrial enterprises [12].

The company has a widespread network of regional divisions. 28 branches, 9 regional directorates, more than 1000 full-time and non-regular insurance agents give the TAS insurance group the opportunity to provide services in all regions of Ukraine [12].

PJSC "Insurance group" TAS is an insurance company offering 106 insurance products from 60 types of complex and specialized programs of voluntary and compulsory insurance.

PJSC "Insurance company TAS Life" (IC "TAS Life") was founded in 2000. Was the first domestic life insurance company. Today the company is one of the leading and most authoritative insurance companies in Ukraine, which offers its clients a wide range of modern programs of individual and corporate life insurance together with high-quality professional services.

PJSC "MetLife" is one of the leaders in the field of life insurance. MetLife leads Insurance TOP ratings in 2017 for key indicators such as: the amount of insurance premiums under cumulative life insurance contracts - 670 million 995 thousand UAH; the number of insured persons under cumulative life insurance contracts - at the end of 2017 more than 112,000 people were insured in the company [11]. This company is the main competitor in the life insurance market for IC "TAS Life".

The National Financial Services Commission has developed a draft Order "On the establishment of additional requirements for life insurance contracts." Its purpose is to strengthen the protection of property rights of insurers - individuals under life insurance contracts, increase the level of public confidence in the life insurance market and create conditions for its sustainable development. The document, in particular, proposes the introduction of additional requirements for life insurance contracts in order to prevent violations of the rights of consumers of financial services, since such contracts are of a longterm nature [8]. As a result, the quality of information disclosure to consumers of insurance services and provision of insurance services will be increased, and the number of complaints about insurers' violation of life insurance financial services legislation has been reduced.

Having also made a detailed examination of insurance legislation, we were able to conclude that, despite important changes and improvements, there remain a lot of unresolved issues regarding the organization of life insurance in Ukraine, namely: 
(a) Association of life insurance with other types of insurance (medical and pension) - as a consequence of increase of sources of income of the insurer, financial provision of insurance indemnity insurance;

(b) The question of the statutory fund of the insurer - the minimum statutory fund of the insurer, determined by the legislation, in our opinion, should increase in line with the growth of insurance premiums in the company for the purpose of their additional security;

(c) Introduction of tax privileges for insured persons (insured) under the programs of shortterm life insurance;

(d) Reinsurance of the insurer in the companies-insurers according to the investment level uaAAA of the National rating scale;

(e) Pension provision through long-term life insurance based on the second level of pension provision;

(f) Expansion of directions of investment and credit activity of the insurance company;

(g) Improvement of the financial analysis of the state of activity for the adoption of corporate decisions.

Consequently, it can be concluded that insurance among the population is in demand. Insurance becomes a necessary component in the system of protection of legal entities and individuals in modern economic conditions. However, in order to determine the insurer, whom a person entrusts life insurance, one must take into account not only the reputation, but also the financial performance of the company.

On May 16, 2008, 10 years ago, Ukraine became a full member of the World Trade Organization. It was the beginning of an important stage in the integration of the country into the world trading system and the global economy. Such changes have also occurred in the field of life insurance.

Based on a detailed analysis and assessment of the effectiveness of life insurance companies and the study of the legal framework, we came to the conclusion that when creating an insurer of life insurance, the company met the law and formed a registered capital of not less than 1.5 million euros for foreign currency the exchange rate of the currency of Ukraine (according to the legislation of Ukraine as of 2001), but for many years of its existence the company does not increase its volume. Since the law states that, 5 years after the accession of Ukraine to the WTO, the registered capital of such a company should be 10 million euros [8].

According to the current legislation, the minimum size of the statutory fund (guarantee deposit) of an insurer engaged in types of insurance other than life insurance is set at an amount equivalent to 1 million euros, and the insurer, which carries out life insurance, 10 million euro at the foreign exchange rate of the currency of Ukraine [8]. Since the company was established in 2000, it is allowed not to increase its authorized capital, but thus, the company loses its leading position among other insurers of life insurance. We believe that TAS Life Insurance Company should start gradually increasing the size of the registered fund now, because such an increase should have taken place 5 years ago.

It was thanks to a detailed financial analysis of the company's operations and estimates that it was possible to identify problems in the financial security of the insurer.

We will calculate the incremental increase based on the fact that the company currently has a registered capital of EUR 1.5 million, an increase of EUR 10 million over 5 years, so we have the result: 
10 million euros -1.5 million euros $=8.5$ million euros;

8.5 million euros $/ 5$ years $=1.7$ million euros per year.

million euros $* 32$ UAH per 1 euro $=54.4$ million UAH per year.

The calculation showed that the company should increase the authorized capital by 1700 thousand euros per year during 5 years in order not to lose its leading position in Ukraine and that if changes in the legislation of the company did not arise a sharp problem of increasing the registered capital. This situation can happen to other insurers, not only Ukrainian, but also foreign insurers.

Therefore, the insurer must gradually increase the authorized capital over 5 years. We propose to make such an increase according to the formulas given in the Methodology section.

The results of calculations are shown in [Table 1].

Table 1. Forecasting an increase in the authorized capital stock [11]

\begin{tabular}{|c|c|c|}
\hline No. & Years & The size of the indicator, million euros \\
\hline 1 & 2019 & 3,2 \\
\hline 2 & 2020 & 4,9 \\
\hline 3 & 2021 & 6,6 \\
\hline 4 & 2022 & 8,3 \\
\hline 5 & 2023 & 10,0 \\
\hline
\end{tabular}

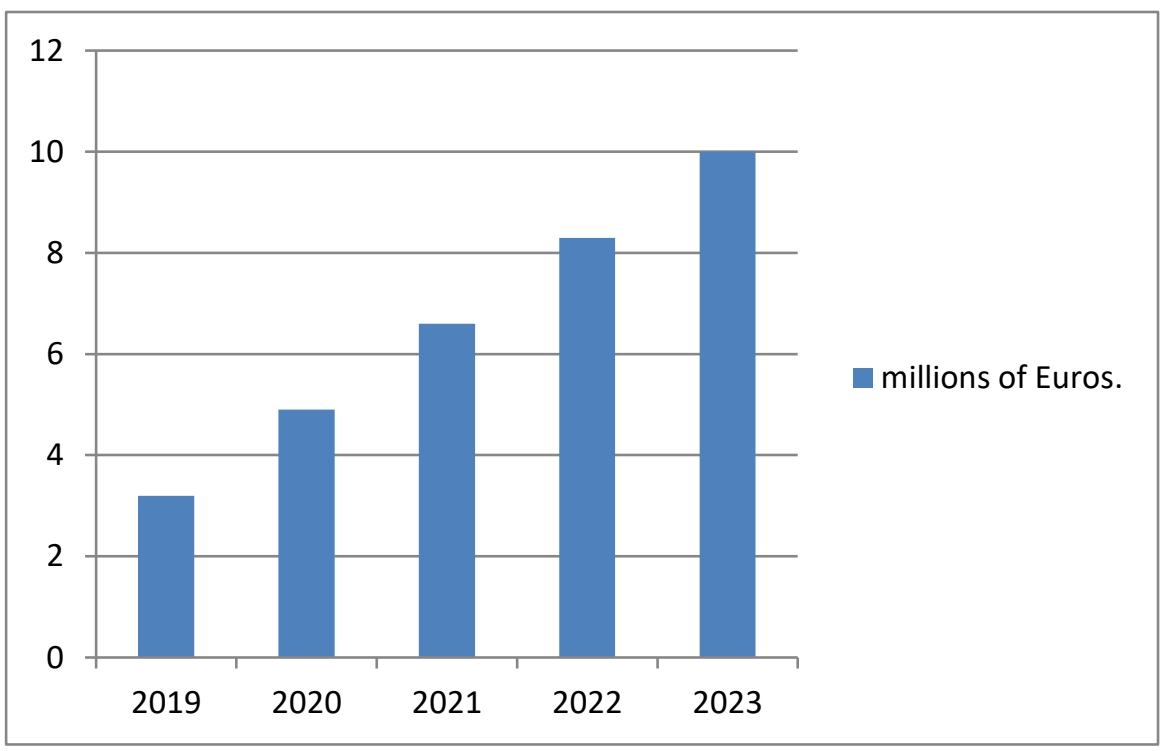

Figure 1. Actual and planning the dynamics of growth of registered capital for 2019-2023

The main source of increase in registered capital may be the company's profit, which is reflected in the total equity of the insurer. If we consider the dynamics of equity and assume that the indicator will increase proportionally each year, then it is possible to calculate the possibility of increasing the registered capital from equity (due to one of its components) [Figure 2]. 


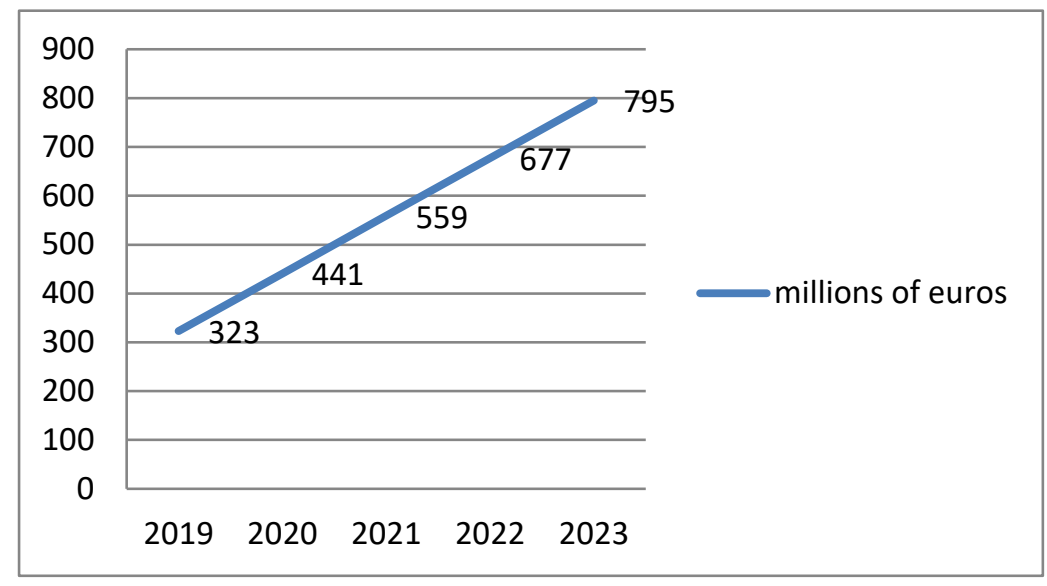

Figure 2. Actual and planning the dynamics of growth of equity for 2019-2023

As [Figure 2] shows, the equity capital of the insurance company is planned to grow, the indicator is projected on the basis of an actual increase in the amount of equity in 2018 relative to 2017 (UAH 250.5 million - UAH 132.9 million = UAH 117.6 million), that is, 117, $6 \mathrm{mln}$. $\mathrm{UAH}$ is the projected amount of increase each year relative to the previous indicator over a period of five years.

Consider the possibility of increasing the statutory fund at the expense of equity on the basis of trend analysis, which is a definition of the main trend of time development of financial reporting. In the simplest case, it can be based on calculations of relative deviations of financial reporting indicators for a number of years from the base year level for which all indicators are taken for $100 \%$.

Trend analysis - comparing each position of reporting with a number of previous periods and determining the trend, the main trend of the dynamics of indicators, cleared from the influence of individual characteristics of individual periods. With the help of the trend, extrapolation of the most important financial indicators for the long-term period is carried out, that is perspective prospective analysis of financial condition [11].

Linear approximation well describes the magnitude that initially increases rapidly, and then gradually stabilizes. Describes both positive and negative values [Figure 3].

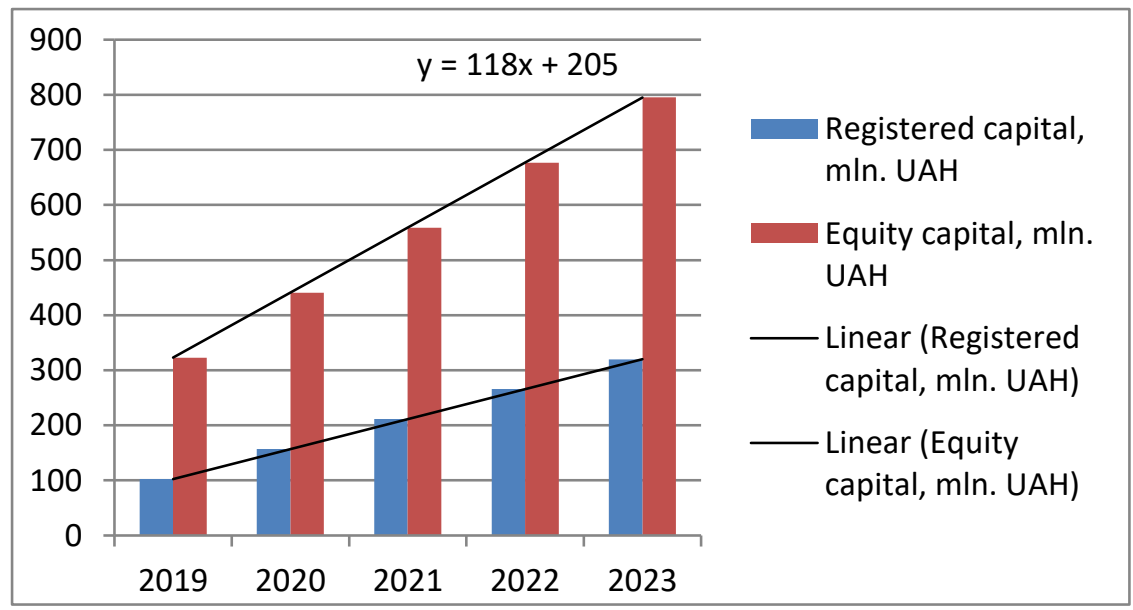

Figure 3. Trend analysis of actual and planned indicators using linear approximation 
On [Figure 3] we observe a steady growth of the equity index, which collectively raises the level of registered capital. If there were indicators of undistributed profits, IC "TAS Life" could predict the growth of registered capital directly at the expense of this indicator. The need to increase registered capital is urgent, as other life insurance companies have taken the leading position in the life insurance market insurance market.

As the forecast shows, the trend line is steadily increasing, but for calculations, we took a compulsory increase in the indicators, we will calculate the trend for actual indicators for five years ahead, based on actual indicators of equity and registered capital.

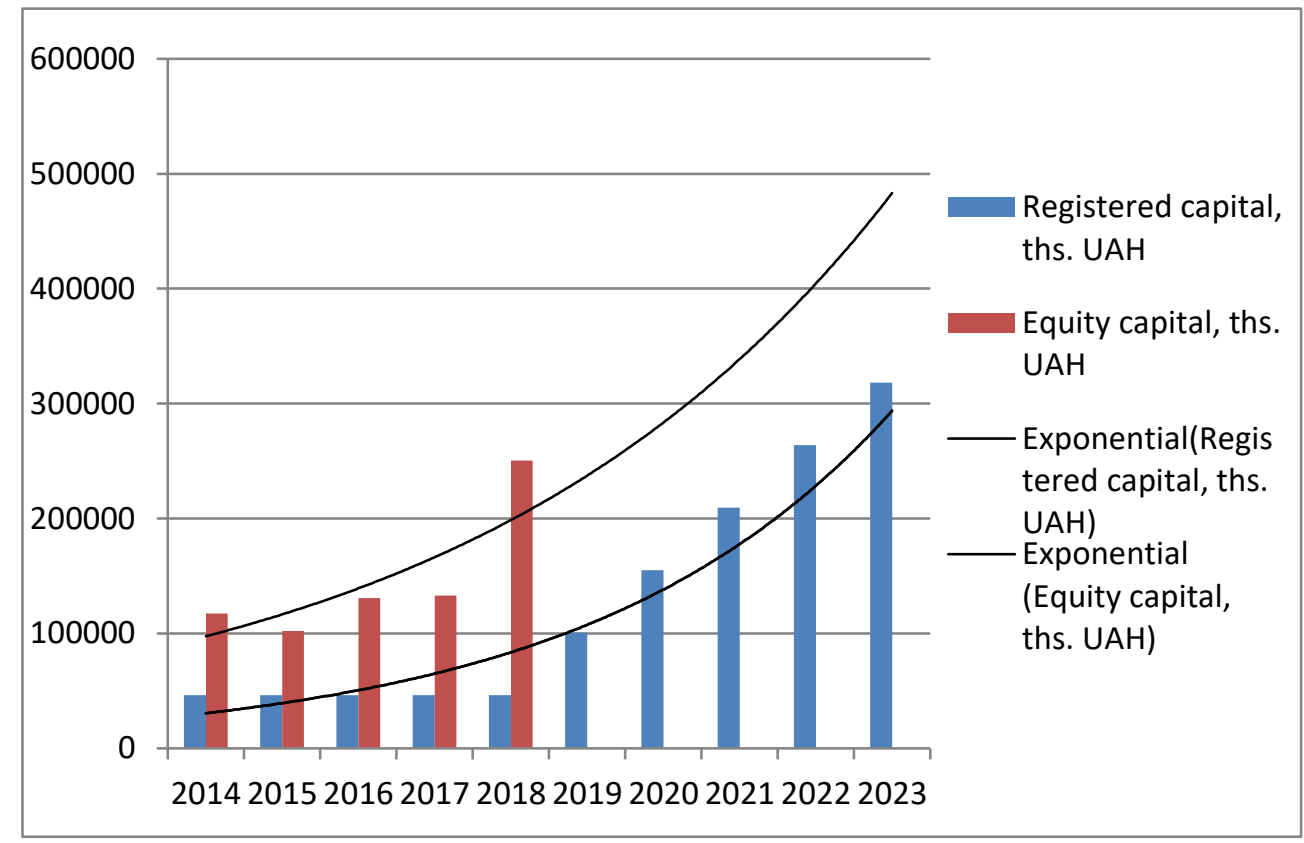

Figure 4. Trend plan for 3 years based on actual indicators using exponential approximation

On [Figure 4], an exponential approximation is used, since it should be used if the rate of data change continuously increases, which happens in our case. Therefore, the forecast of growth of own capital will directly increase the registered capital of IC "TAS Life" in direct proportion.

Thus, the analysis showed that an increase in the registered capital is possible, with a steady increase in the size of the equity of the insurer.

Specialists know that the financial reliability of an insurance company in life insurance is determined by calculating a number of indicators: the ratio of own and attracted capital, liquid assets and short-term receivables, and others. But for such a calculation is required indicators of financial reporting. In many developed countries, rating agencies are involved in the calculation of indicators.

One of the most well-known rating companies is Standard \& Poor's, which uses the rating scale shown in [Table 2] 
Table 2. Rating's scale of reliability of the insurance company [1]

\begin{tabular}{|c|c|}
\hline Rating & Characteristics of the rating \\
\hline AAA & Extremely high ability to fulfill financial obligations; highest rating \\
\hline AA & Very high ability to fulfill financial obligations \\
\hline A & $\begin{array}{l}\text { High ability to fulfill financial obligations, but the element can be damaged by the negative } \\
\text { influence of unfavorable economic conditions and changing circumstances. }\end{array}$ \\
\hline BBB & $\begin{array}{l}\text { Sufficient fulfillment of financial obligations, but greater sensitivity to unfavorable economic } \\
\text { circumstances }\end{array}$ \\
\hline $\mathrm{BB}$ & $\begin{array}{l}\text { Beyond the danger in the short term, but there is considerable uncertainty associated with } \\
\text { sensitivity to unfavorable business, financial and economic circumstances. }\end{array}$ \\
\hline B & $\begin{array}{l}\text { High vulnerability in the presence of unfavorable business and economic conditions, however, } \\
\text { is now possible to fulfill financial obligations }\end{array}$ \\
\hline $\mathrm{CCC}$ & $\begin{array}{l}\text { At present, in danger; The fulfillment of obligations depends entirely on favorable business, } \\
\text { financial and economic conditions }\end{array}$ \\
\hline $\mathrm{CC}$ & At present, it is in great danger \\
\hline $\mathrm{C}$ & $\begin{array}{l}\text { An application for bankruptcy was filed or a similar decision was made, but payments and } \\
\text { financial obligations were met }\end{array}$ \\
\hline $\mathrm{D}$ & Insolvency on financial liabilities (default) \\
\hline
\end{tabular}

In Ukraine, since 2001, the insurance rating "Insurance TOP" - the quarterly edition of the Ukrainian Research Institute of Law and Economic Research, which publishes the ratings of insurers of general insurance and life insurance, as well as insurance brokers, operates. Such ratings are based on the disclosure of indicators of the activities of insurers. It is the need for detailed analysis, comparison, the definition of a number of indicators that characterize the financial position of the company, led to the emergence of rating agencies that group the performance of insurance companies and determine the level of its stability. However, they also do not explore a number of indicators that have a profound financial significance [13].

Each financier must be able to carry out in-depth analysis of the state of the insurance company and its performance indicators. The purpose of such an analysis is to identify the relevance of the indicators and the impact of individual factors on the financial results of the insurer. If Ukrainian citizens do not have financial education, they should apply not only to the results of insurance ratings, but also to the opinions of modern financiers who publish the results of new types of analysis of the life insurance companies and deal with this issue.

\section{Conclusion}

On the basis of research and generalization of the theoretical foundations of life insurance companies, it is proposed to carry out an analysis of the functioning of such companies through the definition of additional indicators (insurance coverage insurance coverage ratio and insurance liquidity ratio), which enabled to improve the system of indicators reflecting financial security, efficiency of companies. Such indicators widely reveal the influence of individual factors on insurance premiums, which are the main source of investment.

An assessment of the effectiveness of the insurer's life insurance is assessed. It was revealed that the performance indicators disclosed by insurance companies do not allow to fully assess their financial status, performance, therefore the internal information of insurance companies, their financial statements are used for analysis. Indicators of public access characterize the activities of the company; the analysis of financial reporting gives a profound assessment. Studies have shown that a comprehensive assessment of the effectiveness of insurers reflects a 
real picture of the financial situation, financial stability, solvency and liquidity of the company, financial attractiveness, as well as the possibility of its bankruptcy.

Consequently, modern financiers consider expedient to carry out in-depth analysis of life insurance companies, which would make the insurer's choice in this field as much as possible.

\section{References}

[1] L. A. Chvertko, T.A. Korniienko, Y. Melnychuk, O. A. Vinnytska, and O. V. Garmatiuk, "Analysis of the factors influencing the market of insurance services in life insurance,” TEM Journal, vol.8, no.1, pp.201-206, (2019)

[2] L. A. Chvertko and T. A. Demchenko, "Travel risks insurance: Problems of theory and practice," Economies' Horizons, vol.1, no.4, pp.66-75, (2018)

[3] D. Cumminsa, M. Rubio-Misasb, and D. Vencappac, "Competition, efficiency and soundness in European life insurance markets,” Journal of Financial Stability, vol.28, pp.66-78, (2017)

[4] G. Veiga and J. McCahery, "The financing of small and medium-sized enterprises: An analysis of the financing gap in Brazil," European Business Organization Law Review, vol.20, pp.633-664, (2019)

[5] Y. Melnychuk, I. Tkachuk, L. Chvertko, M. Slatvinskyi, O. Vinnytska, and T. Korniienko, "Assessment of financial and investment activity of textile enterprises as a guarantee of successful business in the region," Industria Textila, vol.71, no.3, pp.235-240, (2020)

[6] V. A. Omelyanenko, V. V. Martynenko, M. A. Slatvinskyi, I. M. Povorozniuk, N. V. Biloshkurska, and M. V. Biloshkurskyi, "Methodological Bases of Sectoral Innovation Priorities Evaluation within Security-Based Strategies. International Journal of Civil Engineering and Technology, vol.10, no.2, pp.1217-1226, (2019)

[7] N. Rudyk, "EBRD international lending as a source of financing for the development of Ukrainian enterprises," Economic Journal of the Lesia Ukrainian East European National University, vol.2, pp.110-115

[8] The Verkhovna Rada of Ukraine, (2018), On Amendments to the Law of Ukraine "On Insurance": Law of Ukraine, Vidomosti Verkhovnoi Rady Ukrainy, 18, Retrieved from: http://zakon.rada.gov.ua/laws/show/85/96-\%D0\%B2\%D1\%80?find=1\&text=\%D1\%E2\%B3\%F2\%EE\%E2\% $\mathrm{E} 0+\% \mathrm{EE} \% \mathrm{~F} 0 \% \mathrm{E} 3 \% \mathrm{E} 0 \% \mathrm{ED} \% \mathrm{~B} 3 \% \mathrm{E} 7 \% \mathrm{E} 0 \% \mathrm{~F} 6 \% \mathrm{~B} 3 \% \mathrm{FF}$ w21

[9] M. V. Wuthrich, "Non-life insurance: Mathematics and statistics," SSRN

[10] Official site of Fin Post. Retrieved from: https://finpost.com.ua/news/15454

[11] Official site of insurance companies rating (2020). Retrieved from: https://forinsurer.com/insurancetop_76

[12] Insurance Company TAS Life. Official website, Retrieved from: http://www.taslife.com.ua

[13] M. J. Browne and K. Kim, "An international analysis of life insurance demand," The Journal of Risk and Insurance, vol.60, no.4, pp.616-634 